\title{
最近における磁選機の進歩ならびにわが国とその 周域における磁選の記録
}

$$
\text { 八 嶋 } \equiv \text { 郎 }^{1}
$$

\section{は じめに}

磁選法はかなり古くから用いられて来た 分離法であつて, 現在用いられている分離 機の原型が1909年に出版されたGunther ${ }^{1)}$ の著書に既に多数掲載されていることから もその歴史の古さを知ることができょう。 しかしこの分離法あるいは分離機は，その 後絶え間ない磁性材料の進歩に伴つて少し ずつ改良が加えられて来ており, 現在最先 端の分離法としての高勾配磁界を用いた磁 選法あるいは，サマリウムコバルト永久磁 石材料を用いた磁気特性のすぐれた分離機 等の出現となつて来ている。特に高勾配磁 選法の出現は従来の磁選法の概念を越えた 新しい分離法としての側面も持つており， 将来その適用性の拡大が注目されるところ である。

本資料は過去約 40 年間の世界における磁 選機の変遷を述べ，どのようにして今日の 先端技術である高勾配磁選法に到達したか を述べるとともに日本における磁選法の発 達の歴史と現状を述べようとするものであ る。

\section{1. 磁選機における磁界条件の変遷}

磁選機には従来永久磁石を使つたものと 電磁石を使つたものとがある。永久磁石を 使用したものは発生する磁界強度が低く, 常磁性粒子を磁着させるには不適当である。 これに対して電磁石を使用したものにはい わゆるオープン型（磁選が行なわれる空間, すなわち両磁極間のスペースがオープンな もの）とマトリックス型（両磁極間のスペ ースに鉄片，スチールボール，金網，スチ ールウールなどの強磁性物質を詰め, それ を磁化してその中に多数の磁極を発生させ る方式 ) とがあつて, どの装置も鉄の磁気 飽和限度の約 $20,000 \mathrm{Oe}$ の磁界強度を発生で きるものである。しかし後にも述べるが磁 選機の条件として重要なのは磁界の強さ $H$ と磁界の勾配 $(\partial H / \partial x)$ の積 $H(\partial H / \partial x)$ である。第 1 表に代表的な磁選機について 磁界の強さ $H$, 磁界の勾配 $(\partial H / \partial x)$, お よび磁界条件 $H(\partial H / \partial x)$ のそれぞれの目 安となる值を示した ${ }^{2)}$ 。表に見られるよう に, 従来, より弱い磁性の粒子を磁着させ るために強大な磁界を実現させようとする 傾向にあつたが，Hを大とすることには技 術的にも限界があるので，もう一方の磁界 の特性值である $\partial H / \partial x$ を大とし, 合わせ て強大な $H(\partial H / \partial x)$ を実現しようとする
ようになつた。これがKolmら ${ }^{3)}$ の着想にな る高勾配磁選法である。最近は強磁界型磁選 機を強磁力磁選機 (high intensity magnetic separator, HIMS )と高勾配磁選機 (high gradient magnetic separator, HGMS）とに区別して呼ぶすう勢にある。 もつとも磁界の強さとともに磁界の勾配を 強くしようとする考え方は昔からあつたも のでWetherill-Rowand 磁選機あるいは Dings 感応口ール磁選機の磁極構造にも見 られるところであるが ${ }^{4)}$, マトリックス材料 の進歩が高勾配磁選法を現実のものとした ということができよう。

\section{2. 磁選機の分類}

磁選機の分類はいろいろな観点から行な いうると考えられるが ${ }^{a)}$, 磁選機に用いら れる磁界の性質と, 原料の供給方法あるい はベルト型とドラム型の別などによつて分 類すると便利である。ここに記した，原料 の供給方法が上部供給型か下部供給型かは 磁選機の分離特性を大きく左右する重要な 因子であり，またべルト型かドラム型かは 磁選機の分離機構上, 配列している磁極に 対して何を期待しているかを表す，これも また重要な因子である。第 2 表はこのよう な観点から著者らが試みた磁選機の分類で ある。磁界の性質は静磁界か交流磁界かに 大別される。静磁界は弱磁界と強磁界に分 類され，弱磁界型はさらにベルト型とドラ ム型に, 強磁界型はいわゆる強磁界型と高 勾配型に分類され, 交流磁界型は移動磁界 型と振動磁界型と電磁誘導型に分類される。 第 2 表に掲げたそれぞれの分類に属する磁

第1表 各種磁選機の磁界の強さとその勾配ならびに磁界条件

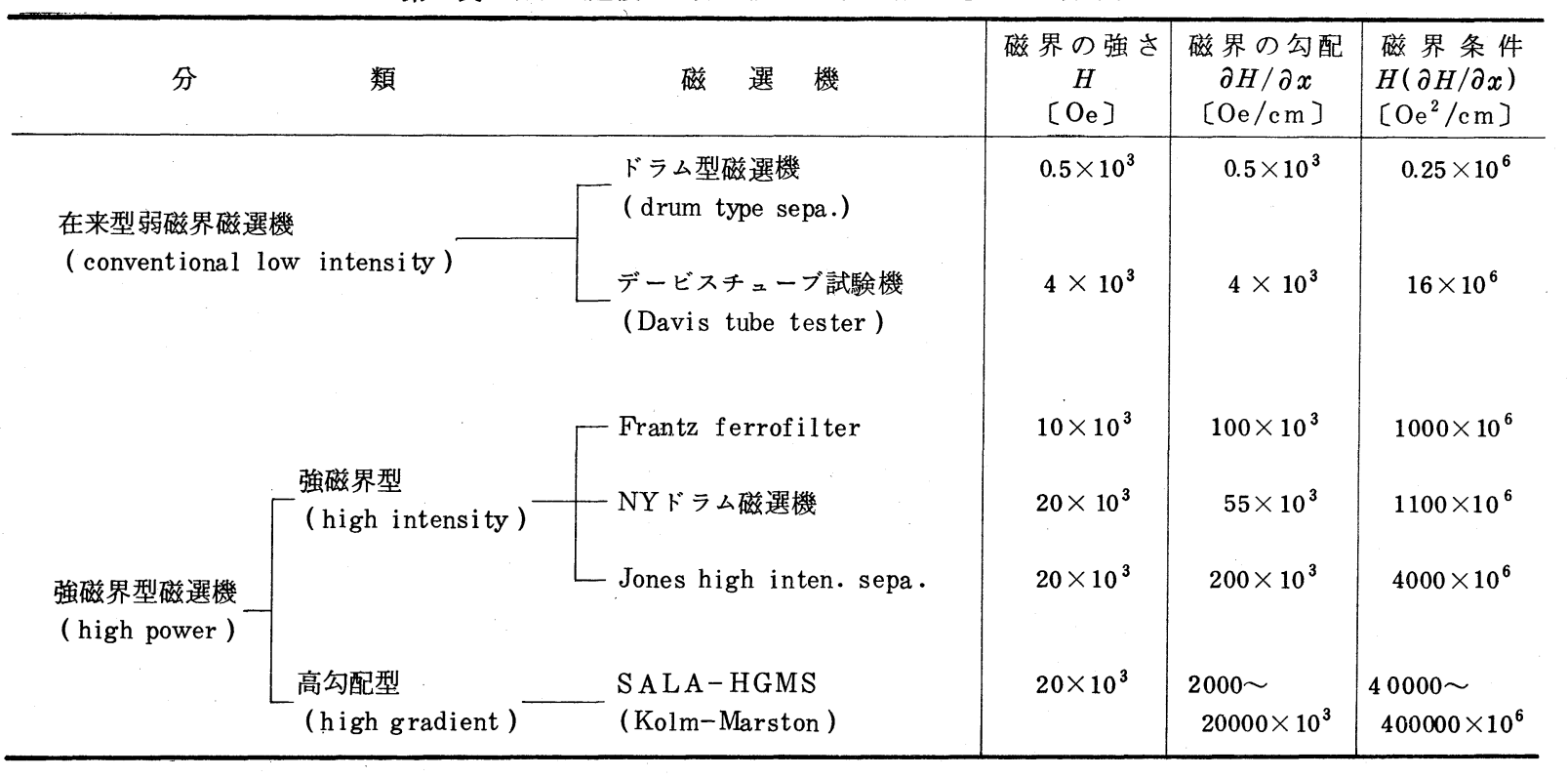

* 1986年8月 5 日受理

1. 正会員 工博 東北大学教授 選鉱製錬研究所

a）加知ら ${ }^{5)}$ は最近新しい分類を試みている。 


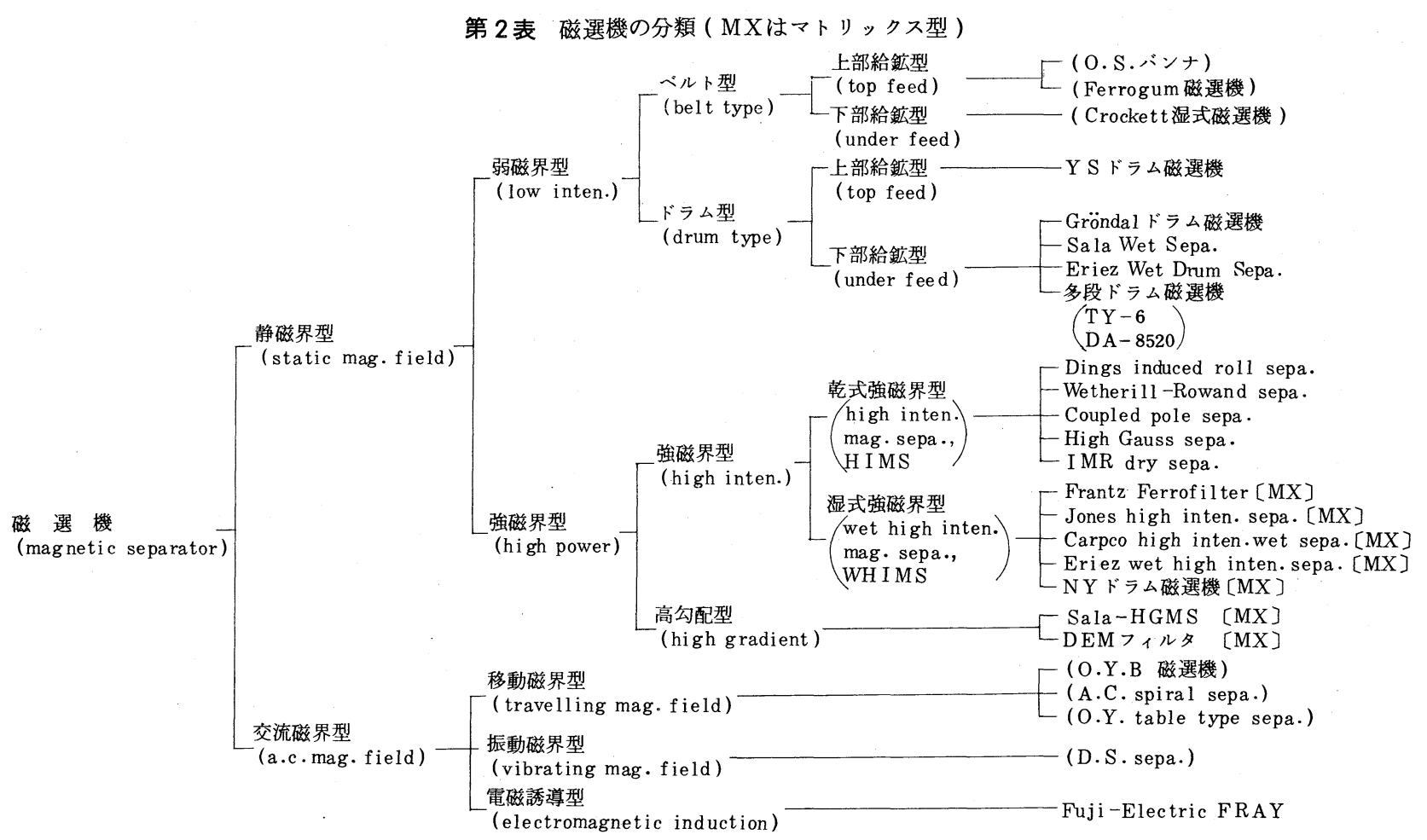

選機の例は過去約 40年間における代表的な もので, 表中（）でくくつたものは過去にお いては大いに活躍した分離機ではあるが既 に磁選機の主流の座を去つたものである。 O.S.バンナ(O.S. vanner $)^{6)}$ と多段ドラ 厶型磁選機 (multi-stage drum separator $)^{7)}$ は日本で開発された砂鉄用の分離機 であつたが，砂鉄鉱山の閉山に伴つて姿を 消した。Ferrogum 磁選機8) も日本で開発 きれたものであり, 主として精選用であつ たが今は使われていない。かつて弱磁界型 の主流の分離機であつたCrockett 湿式分 離機も既に姿を消しているが，その理由は 後に述べる。磁鉄鉱を主体とする製鉄用原 料が弱磁界型磁選機で最も大量に処理され ている鉱石であるが，これに用いられてい る磁選機の主流は今やドラム型分離機であ る。交流磁界型では移動磁界型, 振動磁界 型ともにその精選効果が極めてすぐれてい ることは認められながらも, 処理容量が少 ないという難点を克服することができず, 遂に実用機からは姿を消している。近年に 至り，製鉄原料のへマタイトあるいは特殊 原料の処理に強磁界型が広く用いられるよ うになり，多様な磁選機が開発されて使用

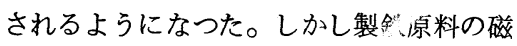
選を除けば，その分離機の種類が多い割に は処理されている鉱石の量は少ない。この 強磁界型でも特徵ある分離機は高勾配型で ある。

第 2 表に掲げた各種の磁選機のうち, O. S.バンナ, Ferrogum磁選機, Crockett 湿式磁選機, Gröndal ドラム型磁選機, N
Yドラム型磁選機, Wetheri11-Rowand磁 選機, Dings 感応ロール磁選機については 本文中に引用した文献に詳細に記載されて いる。またFranz Ferrofilter, Jones 強 磁界磁選機, Carpco 強磁界湿式磁選機, Eriez 湿式強磁界磁選機, Sala高勾配磁選 機の構造と分離機構については既に報告し た総説 ${ }^{9)}$ と技術展望 ${ }^{10)}$ および著書 ${ }^{11)}$ に述 べたので重複を避けるために眓などは省略 した。対極型磁選機，O.Y.B.分離機，A. C.スパイラル分離機，O.Y.テーブル型分 離機, D.S. 型分離機についても構造と分 離機構を既刊の著書 ${ }^{12)}$ にまとめて紹介した のでこれらも省略した。

HIMSでの新しい分離機はHigh Gaussセパレータ (神鋼電機) と I M R 乾式分 離機（日本エリーズマグネチックス）である。 前者は原理的には既述のWe therillRowand 分離機と同じで，電磁石を用いた 対向磁極型であり，供給ベルトとピックア ップベルトが直交していて, 供給ベルトを 振動させることができるようになつている。 I M R 乾式分離機はDings感応口ール型と 同じ原理で，多段ロール方式をとつており， 乾式分離に多く用いられている。 HGMS のDEMフィルタ（大同特殊鋼）はわが国 で開発された高勾配磁選機でサイクリック 型であり，製鋼プラントなどの廃水処理に 多く用いられている。交流磁界型の中の電 磁誘導型は磁力を利用した分離機というよ りは，うず電流と磁界との相互作用によつ て非鉄金属片を分離するものであるが，交 流磁界の新しい利用として表中に記した。

\section{3. 弱磁界磁選}

数千 Oe までの比較的弱い磁界を持つた 磁選機による分離はわが国では従来よく用 いられて来た。その対称となる鉱石は磁性 の強い鉱石で, 磁鉄鉱, 砂鉄, 磁硫鉄鉱, 製錬産物などである。

\section{$3 \cdot 1$ 鉄鉱石の磁選}

（1）磁鉄鉱の磁選 わが国における磁 鉄鉱の磁選で最も古く，長い歴史を持つて いるのは鉒石鉱山 ${ }^{13)}$ である。1716〜1736年 に開山された鉱山で，はじめは鉄鉱石を採 掘したまま売鉣し，次いで破砝・ふるい分 け・水洗を行なつて売鉱していたが，搬出 する粗鉱量が増大するのに伴つて1936年に はじめてGröndal ドラム型磁選機を導入し て当初粉鉱の処理を行なつた。このGröndal ドラム型磁選機は1902年にスエーデン の技術者Gustaf Gröndalによつて考察さ れたものであつて ${ }^{14)}$, わが国では，それか ら34年経た1936年に釜石鉱山で初めて用い られるようになつた。

釜石鉱山では1938年頃から鉄鉱石の湿式 磁選尾鉱中の銅分を回収するために浮選工 場が増設され, 現在は鉄系統, 銅系統と 2 系統あり, 鉄粗鉱 2,500 t/日，銅粗鉱 $770 t /$ 日, 鉄銅粗鉱 1,400 t/日を処理している ${ }^{15)} 。$ この 2 系統ともに 1944 年から粉鉱処理のた めにCrockett 湿式磁選機が導入されてい るっこのCrockett 湿式磁選機は三菱電機の O P 磁石を利用した永久磁石型で, 後に述 べる茂山鉱山に導入された電磁石型Crockett 湿式磁選機の改良型である。Crockett 
湿式磁選機は1933 年に世に出たもので ${ }^{16) 17)}$ わが国にはそれから11年経た1944年に導入 されている。古い歴史を持つたベルト型の 磁選機ではあるが, ドラム型磁選機に比べ て据付床面積当りの処理容量が小さく, 工 場の集中制御にはドラム型のほうが適して おり, またCrockettのほうがスライムの抱 き込みが多いなどの欠点があり ${ }^{18)}, 1968$ 年 これを撤去してSala の $600 \phi \times 1700$ 型のド ラム型磁選機（磁界の強さ：ドラム面から $25 \mathrm{~mm}$ で 1,400 Oe )を新設した。1968年に は三菱電機と共同開発した大型強力ドラム 型磁選機, DA1020A ( 磁界の強さ：ドラ 么面で $3,600 \mathrm{Oe})$ を増設して, 尾鉱の磁鉄 鉱の $\mathrm{Fe}$ 品位を従来の $3 \%$ から $0.5 \%$ に低下 させている。

以上は主として粉鉱の湿式磁選であるが， 乾式磁選では, はじめ手選にかわる塊鉱処 理の方法として，鉄板製ドラムを用いた電 ·磁石型 Gröndal 分離機を 1944 年に鉒石鉱 山で試作して用いている。次いで1949年に 塊鉱の片刃粒子の処理を計画し, ミル給鉱 をコーンクラッシヤで破砕して2.0 6 $\mathrm{mm}$, $6 \sim 3 \mathrm{~mm}, 3 \mathrm{~mm}$ 以下に整粒し, これを乾 式電磁石ドラム型分離機で分離している。 この鉄板製ドラム型磁選機は釜石鉱山独得 のものであるが，これとは別に鉄板製ドラ

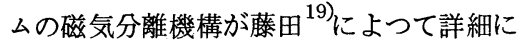
研究されている。

磁鉄鉱々山として稼行されていたもうひ とつの鉱山は北朝鮮と中国の東部国境付近 にある茂山鉱山である。茂山鉱山は1916 年 ころの開山で, 1936年に茂山鉱山開発 (株) によつて 70,000t/年の試験選鉱場が完成し, その後かなり大規模な選鉱場を建設してい る。主な選鉣法は磁選法で, 電磁石型の ドラム型分離機 $(700 \sim 1,000 \mathrm{Oe})$ を細粒に, マグネチック・プーリーを粗粒に用いる一 方Dings 製の電磁石型Crockett 湿式磁選 機 (700 900 Oe ) を用いている。この電 磁石の損耗が大きいので, これを三菱電機 が改良してO P 磁石を用いた永久磁石型と している。これを1944 年に釜石鉱山が採用 したことは前述のとおりである。茂山鉱山 は1945年まで稼行された ${ }^{20)} 。$

国内の磁鉄鉱鉱山には釜石鉱山のほかに 江刺鉱山と秩父鉱山がある。江刺鉱山は1983 年の開山であり, 1972年には粗鉱 $10,000 t /$ 月を処理している ${ }^{21)}$ 。浮選で銅鉱石を採取 した尾鉣から磁選で磁鉄鉱を回収している。 この選鉱場のおもな磁選機は Sala の $600 \phi$ ×2400ドラム型であつたが, そのほか東和 選鉱機の TY $-10(750 \phi \times 950)$ ドラム型, 三菱電機のDA-820A ( $806 \phi \times 950)$ ドラム 型などが使われていた ${ }^{22)}$ 。この鉱山は 1977 年に閉山している。
一方1937年から稼行を開始した秩父鉱山 では磁鉄鉱と黄銅鉱をFerrogum 磁選機 (300 Oe ) で分離し, 磁鉄鉱を回収してい $3^{23)}$ 。同鉣山では 1968 年に粗鉣 $322,000 t /$ 年を処理していた。なお久根鉱山でも 1960 年から1970年まで, キースラガー中の磁鉄 鉱をFerrogum 磁選機で分離していた ${ }^{24)}$ 。 秩父鉱山, 久根鉱山をもに今は閉山してい る。

国外の磁鉄鉱鉱山としては香港の馬鞍山 鉱山がある。この鉱山は 1910 年に英国人が 発見したもので, 1941年日本製鉄が開発に 着手し, 1945 年以降は大公洋行が開発を続 け，1952年に八幡製鉄と日鉄鉱業で試錐探 查を実施して700万tの埋蔵量を確認した後 1954年に日鉄鉱業が磁力選鉱場を建設して 大公洋行に貸与し, 採鉱, 選鉱技術の指導 を行なつて, 精鉱品位, T. $\mathrm{Fe}=56 \sim 57 \%$

(1970年より, T. $\mathrm{Fe}=50 \%$ に変更) の産物 を対日輸出していた。選鉱場の処理能力は $\mathrm{T} . \mathrm{Fe}$ 約 $30 \%$ の粗鉱 15,000 t/月 で, T.Fe 約 $56 \%$ の精鉱を $10,000 \mathrm{t} /$ 月生産していた。当 初使用した磁選機は Gröndal ドラム型 (電 磁石式 ) が 2 台, Crockett 型(OP磁石式) が 4 台, ドラム型 (OP 磁石式) が 1 台であ つたが, 後にはCrockettの使用を中止して いる。馬鞍山鉱山は1975年まで操業を続け 閉山した ${ }^{25) 。 ~}$

（2）赤鉄鉱のばい焼磁選 中国東 北部 (旧満洲) の鞍山製鉄所 (1933年に昭 和製鋼所となる) では赤鉄鉱と硅石とが緻 密に混合した含鉄硅岩とも称すべき負鉄鉱 (Fe $40 \%$ 以下) を還元ばい焼し, 強い磁性 を付与した後湿式磁選法で分離する，い わゆるばい焼磁選法を行なつていた。1920 年 1 月から本法を適用するための組織的研 究に着手し, 1922年 6 月鞍山式貧鉱処理法 を完成して特許権を獲得し, 1923年10月選 鉱場建設に着手して, 1926年 7 月に竣工し, 操業を開始している。選鉱場の処理容量は， 高炉銑鉄生産量 $200,000 \mathrm{t} /$ 年に対応するも のとして, 原鉱石処理能力 $2,000 \mathrm{t} /$ 日, 団 鉱生産量 $1,000 \mathrm{t} /$ 日であつた。この選鉱場 に設備された磁選機はGröndal ドラム型 (ドラムの直径 $770 \mathrm{~mm}$, 長さ $865 \mathrm{~mm}$, 電磁 石の電圧と電流 $110 \mathrm{~V}, 12 \mathrm{~A}$, 回転速度 30 $35 \mathrm{rpm}$, 所要動力 $3 / 4 \mathrm{H}$, 処理量 $2 \mathrm{t} / \mathrm{h}$ ) 54 台, アイアランス・マグネチック・ウェ ツトセパレータ (ドラムの直径, $770 \mathrm{~mm}$, 長さ $843 \mathrm{~mm}$, 電磁石の電圧と電流 $110 \mathrm{~V}$, $12 \mathrm{~A}$, 所要動力 $1 \mathrm{H}$, 処理量 $5 \sim 8 \mathrm{t} / \mathrm{h}$ ) 1 台, マグネチック・マァニュファクチュ アリング社製 (ベルトの幅, $30 \mathrm{in}$, ベルト の傾斜28度, 電磁石の電圧と電流 $110 \mathrm{~V}$, $12 \mathrm{~A}$, 処理量 $1.5 \sim 2 \mathrm{t} / \mathrm{h}) 1$ 台, Dings磁 選機 1 台の合計57台で, Gröndal ドラム型
以外の磁選機は比較研究のために設備され たものである。選鉱成績は1931年度につい てみると, 精鉱品位 $\mathrm{Fe}: 58.57 \%, \mathrm{FeO}$ : $19.75 \%, \mathrm{Si} \mathrm{O}_{2}: 17.94 \%$, 尾鉱品位 $\mathrm{Fe}$ : $14.03 \%, \mathrm{FeO}: 2.70 \%$, 鉄分回収率 83.22 \%で，この年度における精鉱生産量は $371,753.5 \mathrm{t}$ であつた。

極東地区で工業的規模で操業されていた ばい焼磁選法の唯一の記録として,ま た電磁石式のドラム型とベルト型磁選機が 初めて導入された記録としてここに記した 26) 33)。この工場は今も大規模に操業され ているという。

（3）砂鉄の磁選 1940年代から 1960 年代にかけて日本では 砂鉄が高炉用と電 気炉用として盛んに採掘選鉱された。主な 選鉱法は磁選法である。砂鉄は $\mathrm{FeO}-\mathrm{Fe}_{2} \mathrm{O}_{3}$ $-\mathrm{Ti} \mathrm{O}_{2} 3$ 成分系鉱物で，通常 $10 \%$ 前後の $\mathrm{TiO}_{2}$ を含んでいる。この砂鉄の生産量は 1955 年で $575,500 \mathrm{t}$ である ${ }^{34)}$ 。海岸砂鉄と山 砂鉄とがある。現在はほとんど掘り尽くさ れている。この砂鉄の選鉱には第 2 表のO. S.バンナーが粗選用として, またFerrogum磁選機が精選用としで使われたことも ある。当初はCrockett 湿式磁選機がよく 用いられていたが, 前述の理由で後にドラ ム型磁選機が用いられるようになつた。特 に多段ドラム型磁選機 $\left.{ }^{\mathrm{b}}\right)(\mathrm{TY}-6, \mathrm{DA}-$ $8520)$ はわが国独得のもので, 現場に専門 の選鉱技術者がいなくとも十分に効率のよ い分離が行なえるように, その構造が工夫 されていた。

（4）磁硫鉄鉱の磁選 わが国で磁硫鉄 鉱を本格的に処理していたのは河山鈗山と 柵原鉱山である。河山鉱山は1936年に開山 し, 1970年に閉山した。1960年の粗鉱取扱 量は 360,000 七であり, 磁界の強さが 2,500 Oeと比較的強いCrockett 湿式磁選機を用 いて選鉣を行なつていた ${ }^{35)}$ 。

一方, 柵原鉣山 ${ }^{36)}$ は1918年に開山して以 来磁硫鉄鉱の選鉱を行なつて来たが, 1961

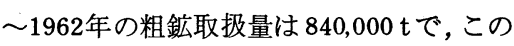
うち 240,000 tが磁硫鉄鉱であり，磁選には 強力ドラム型磁選機である接面磁選機 ( $7000 \mathrm{Oe})$ を用いている。

\section{$3 \cdot 2$ 銅製鍊スラグとフェロニッケルの 磁選}

佐賀関製錬所では銅製鍊における転炉鍰 $\left(\mathrm{Fe}: 48 \%, \mathrm{SiO}_{2}: 20 \%, \mathrm{Cu}: 4 \%\right)$ とと もに鈹 $(\mathrm{Cu}: 78 \%)$ を破研して磁選を行な つている ${ }^{37) ~ 39)}$ 処理量は 20,000 t/月であ つて, 使用している磁選機は電磁石式ドラ ム型分離機 $(1,800 \mathrm{Oe})$ であり, $18 \mathrm{~mm}$ 以

b）ここに述べた砂鉄用のTYー6 あるいはDA8520 とは別にSalaとEriezによつて多 段ドラム型の磁選機が開発されている。 
下の粒径として供給している。鍰について は $\mathrm{Cu}: 6.27 \%$ の原料を分離して, $\mathrm{Cu}: 68.8$ \%の精鉱を $\mathrm{Cu}$ 実収率 $44.9 \%$ で回収してお り, その際の尾鉱の品位は $\mathrm{Cu}: 3.61 \%$ であ る。:鈹についてはCu: $31.2 \%$ の原料を処理し て $\mathrm{Cu}: 59.3 \%$ の精鉱を $\mathrm{Cu}$ 実収率 $67.3 \%$ で 回収し, その際の尾鈗の品位は $\mathrm{Cu}: 15.9 \%$ である。

つぎに大江山ニッヶルでは A O D プロセ スでガーニェライトを処理して, フェロニ ッケルのルッペを磁選している。1979年の. ニッケルの生産量は 9,910 七である。使用し ている磁選機は永久磁石式ドラム型（磁界 の強さ $1,650 \mathrm{Oe}$ ) と電磁石式ドラム型（磁 界の強さ $1,800 \mathrm{Oe}$ ) である。原料の粒径は 1 $\mathrm{mm}$ 以下であつて, 金属分含有率が約 $3 \%$ であるが，これを鈗液濃度約 $5 \%$ で毎時 30 ～60 t を供給し, 湿式で分離している。磁 選精鉱の Ni 品位は18〜22\%である ${ }^{40) 41}$ 。

\section{$3 \cdot 3$ 製鋼スラグの磁選}

日本磁力選鉱 (株)は1955年 以来今日まで 日本における11の製鋼工場においてスラグ から鉄資源の回収を行なつている。1980年 における処理量は $3,657,000$ t であり, 磁選 による回収産物は合計 $2,268,090$ t である。 使用している磁選機は自社製の電磁石式ド ラム型 (磁界の強さ $2,300 \sim 2,500 \mathrm{Oe}$ ) と永 久磁石式ドラム型（磁界の強さ $1,500 \mathrm{Oe}$ ) と吊下型電磁石 (磁界の強さ $2,300 \sim 2,500$ Oe )である ${ }^{42)}$ 43)。

\section{4. 強磁界磁選 ( H I MS )}

前章で述べた弱磁界磁選は実用技術とし てはほぼ完成の域に達したもので, 主とし て製鉄原料を処理するため取り扱い鉱量も 極めて多く，わが国における磁選の主流を なすものであろう。これに対して強磁界磁 選では取り扱われる鉱量はそれほど多くは ないが，処理される原料は多種類にわたる ものと思われる。

この強磁界磁選では従来からWetheril1Rowand 磁選機あるいはDings 感応ロール 磁選機などが小規模に用いられて来たが， 実用的規模で強磁界磁選が用いられたのは Coupled Pole magnetic separator (日 本磁力選鉱の対極型磁選機 ) と I M R separator(日本エリーズマグネチックス) が開 発されてからであろう。以下に幾つかの実 施例を述べる。

（1）対極型磁選機による長石の精製

陶磁器用原料としての台湾産長石から強 磁界磁選で黒雲母を除去するもので, N J $(50+50)$ 対極型磁選機を用い, 26,000 Oe で, 14〜 100 mesh $82.3 \%$ の粒度の原料 を $500 \mathrm{~kg} / \mathrm{h}$ の処理量で分離した。精製され た長石は化学分析とX線回折を行なつた結
果, 陶磁器用原料として極めて良質であり, $\mathrm{N} \mathrm{J} \mathrm{G}(150+300+150)$ 対極型磁選機を用 いると $4,000 \sim 5,000 \mathrm{~kg} / \mathrm{h}$ の処理量で分離 することができるものと考えられている44。

（2）対極型磁選機によるクロマイト砂の 分離 わが国で用いられているクロマイ 卜鋳物砂は南アフリカから輸入されており, 年間 $20,000 t$ 用いられている。その鉱物組 成は $(\mathrm{Mg}, \mathrm{Fe}) \mathrm{O} \cdot(\mathrm{Cr} \cdot \mathrm{Al} \cdot \mathrm{Fe})_{2} \mathrm{O}_{3}$ であ る。これを循環使用するために対極型磁選 機を用いて $\mathrm{Fe}$ 分と $\mathrm{SiO}_{2}$ 分を除去してク口 マイト砂としての純度をあげている。その 型式についての記録はないが, $27,000 \mathrm{Oe}$ の磁界の強さのもとで分離を行ない, 良好 な成績をえているという ${ }^{45) 。 ~}$

（3） I MR 分離機による各種粉体の分離

$I M R$ 分離機は感応口ール型の便利な 分離機として, 鋳物砂, 耐火物原料等各種 窯業原料, 金属粉などの処理に広く用いら れ, その使用台数も約 160 台の多数にのぼ つている ${ }^{46)}$ 。

\section{5. 湿式強磁界磁選（WH｜MS）}

湿式強磁界磁選機には第 2 表に揭げたよ うに Jones high intensity separator, Carpco high intensity wet separator, Eriez wet high intensity separator, NY drum separator があるが, ここには その例としてEriez型と, NY drum型にう いて述べる。

(1) Eriez wet high intensity separator この型式の分離機はいわゆる マトリックス型で, 相対する磁極間のスペ ースにスチールボール, エキスパンドメタ ル, スチールウールなどのマトリックスを 充てんし，これらが磁化されて，そのエッ ジの部分に生ずる強大な磁界に磁性粒子を 捕捉して分離を行なおうとするものである。 後に述べるSala HGMS では磁束の方向 と供給するパルプの流れの方向が平行であ るのに対し, この型式のものでは両者が直 交しているのが特徴である。瀬戸地区で, CF-10 型を用いてビンガラス用硅砂の磁
選を行ない，原鉱中の $\mathrm{Fe}_{2} \mathrm{O}_{3}$ の $78.5 \%$ を磁 選精鉱として採取し, $\mathrm{Fe}_{2} \mathrm{O}_{3}$ の含有量が $0.028 \%$ 製品を得ることができ, そのとき の操作条件は給鉱速度 $1.30 \mathrm{t} / \mathrm{h}$, パルプ濃 度 $26.0 \%$ \%あつたという報告がある ${ }^{46)}$ 。こ の方式の磁選機は昭和59年度までに 111 台 使用されており (中国, ブラジル，ビルマ， パキスタン向けの 6 台を含む), そのうち 硅砂と粘土の脱鉄に使用されているものが $63 \%$ である ${ }^{47)}$ 。

（2）NYドラム型磁選機による低品位二 ッヶル鉱セグリゲイション産物の分離 低品位酸化ニッケル鉱のセグリゲイション 産物を, 永久磁石式ドラム型磁選機のドラ ムの表面に直径約 $10 \mathrm{~mm}$ の鋼球を多数配列 した強磁界磁選機で分離回収したもので, $80 \%$ 通過粒径が $17 \sim 20 \mu \mathrm{m}$ の微粒の原料を ドラムの単位有効幅当り, 毎時 $0.02 \mathrm{t}$ の処 理量で分離して良好な結果をえたと報告さ れている ${ }^{48)}$ この分離機はドラムの表面に 多数配列した鋼球と鋼球の接点に生じる強 大な磁界によつて分離しようとするもので, 第 1 表にも掲げたように, 接点付近の磁界 の条件は $H(\partial H / \partial x)=1100 \times 10^{6} \mathrm{Oe}^{2} /$ cm であり, HI MS から次に述べる HG $\mathrm{MS}$ への過渡期の分離機と考えることがで きる。

\section{6. 高勾配磁選 ( H G MS )}

高勾配磁選法は1968年にKolm らによつ て開発されたものである。わが国では各所 でその分離機構の研究と適用性試験が進め られており，また実操業に用いられている ものもある。分離機構についてはマトリッ クスを構成する細線に対する微粒子の磁着 の機構をforce balance model あるいは particle trajectory model で理論的に 説明しょうとしてい.る段階で, 粒子の大き さ, 粒度分布, 鉱液濃度あるいは給鉱速度, 流速, 磁界の強さなどの操作要因と分離性 との関連についての一般的な解はない。第 3 表はわが国におけるSala 高勾配磁選機 の使用状況である ${ }^{49)}$ 。1986年 1 月現在で合

第3表 Sala-HGMSの使用状況

\begin{tabular}{|c|c|c|c|}
\hline 途 & 実 用 機 & 試 験 機 & 小 計 \\
\hline $\begin{array}{ccc}\text { 鉱 物 処 } & \text { 理 } \\
\text { 寭 業, 触 媒 }\end{array}$ & $\begin{array}{l}4 \text { 基 } \\
\text { ( カローセル型 } 1 \\
\text { を含む） }\end{array}$ & $\begin{array}{c}13 \text { 基 } \\
(\text { カローセル型 } 1 \\
\text { を含む) }\end{array}$ & $\begin{array}{l}17 \text { 基 } \\
(\text { 内力ローセル型 } \\
2 \text { ) }\end{array}$ \\
\hline $\begin{array}{l}\text { 鉄 鋼 プ } \\
\text { 廃 水 処 }\end{array}$ & 6 & 2 & 8 \\
\hline $\begin{array}{c}\text { 発 } \text { 電 } \\
\text { 水 } \\
\end{array}$ & 9 & 4 & 13 \\
\hline 小 & 19 & 19 & $\begin{array}{l}\text { 合 } 38 \text { 基 } \\
\text { 計 }\end{array}$ \\
\hline
\end{tabular}

1986年 1 月現在 
第4表 DEMフィルタの使用状況

\begin{tabular}{|c|c|c|c|c|}
\hline 分野 & 用 途 & 対 象 & 実用機 & 試験機 \\
\hline \multirow{8}{*}{$\begin{array}{l}\text { 鉄 } \\
\text { 鋼 }\end{array}$} & \multirow[t]{7}{*}{ 廃水処理 } & 熱間圧延冷却水 & 12基 & \multirow{6}{*}{0 基 } \\
\hline & & 連鋳スプレー水 & 6 & \\
\hline & & $\begin{array}{r}\text { 脱ガスコンデンサー } \\
\text { 冷却水 }\end{array}$ & 4 & \\
\hline & & 探傷用冷却水 & 6 & \\
\hline & & 冷延アルカリ脱脂液 & 4 & \\
\hline & & その他 & 7 & \\
\hline & & & 小計 39基 & 0 \\
\hline & 油分回収 & 冷延クーラント & 3 & 0 \\
\hline \multirow{2}{*}{$\begin{array}{l}\text { 発 } \\
\text { 電 }\end{array}$} & \multirow{2}{*}{\multicolumn{2}{|c|}{$\begin{array}{l}\text { 冷 却 水 } \\
\text { 液体ナトリウム }\end{array}$}} & 0 & 3 \\
\hline & & & 0 & 2 \\
\hline \multirow[t]{3}{*}{ その他 } & \multicolumn{2}{|c|}{ 産業廃水処理（重金属等） } & 0 & 1 \\
\hline & \multicolumn{2}{|l|}{ 小 } & 42基 & 6 基 \\
\hline & \multicolumn{2}{|l|}{ 合 } & \multicolumn{2}{|c|}{48 基 } \\
\hline
\end{tabular}

他にサイクリック型全自動試験装置： 2 基

1985 年 8 月現在

計38基が使用されている。このうち実用機 は19基でこの中にはカローセル (carouse1) 型が 1 基含まれており，乾式で石油精製用 触媒の処理に用いられている。他はサイク リック ( cyclic) 型である。試験機として 使用されているものは全部で19基あり，こ のうち 1 基がカローセル型で他はサイクリ ック型である。表に見られるように実用機 では発電プラントの水処理に用いられてい るものが最も多く,ついで鉄鋼ブラントの 廃水処理に用いられているもの, 鈗物処理, 害業原料処理と触媒処理に用いられている ものの順となつているが，試験用としては 鉱物処理関係で用いられているものが最も 多く, ついで発電プラント用, 鉄鋼プラン トの廃水処理用の順となつている。

第 4 表はDEMフィルタの使用状況であ $3^{50)}$ 。1985年 8 月現在で合計 48 基 (内 2 基 は海外で ) 使用されており，実用機が42基 試験機が 6 基で, 実用機は全部鉄鋼関伭の プラントの廃水処理と油分の回収に用いら れている。この48基のほかに全自動試験装 置 2 基がメーカーに設備されている。

（1）Sala HGMSによる粘土の精製

共立割業原料(株)では1981年以来河東力 オリンと天草粘土をSala HGMSによつて 精製し, よい成績をえている。処理量は 1 $\sim 1.5 \mathrm{t} / \mathrm{h}$ で, $\mathrm{Fe}_{2} \mathrm{O}_{3}$ の除去率が50 70\%, $\mathrm{TiO}_{2}$ の除去率が $50 \sim 60 \%$ あり，精製さ れた粘度による焼成品の白色度が精製しな かつた粘度を用いた焼成品の白色度に比べ て著しく改善され，加えてHGMSにより 精製した粘度を用いたセラミックス工場で は成型品の歩留が著しく改善されたといわ れている ${ }^{51)}$ 52)。

（2）DEMフィルタによる鉄鋼冷延クー
ラントの処理

第 4 表に掲げるよ

うに大同特殊鋼の

DEMフィルタは主

として製鉄製鋼プ

ラントの廃水処理

と油分回収に使用

されているが, こ

れらのうち鉄鋼冷

延クーラントを処

理した操業成績を

述べると, 原液の 性状は油分濃度 1

$\%$, 鉄分含有率

$360 \mathrm{ppm}$ で, これ を磁束密度 3000 $\mathrm{G}$, フィルタ直径 $1000 \mathrm{~mm}$, 流速 $400 \mathrm{~m} / \mathrm{h}$ の基本仕 様の装置によつて, $265 \mathrm{~m}^{3} / \mathrm{h}$ の供給速度で処理して油分回収 率 $98.9 \%$, 鉄分除去量 $15 \mathrm{~kg} / \mathrm{h}$ という成績 をえている ${ }^{53)}$

（3）高勾配磁選法の適用性に関する研究 の現状 高勾配磁選法の各種鉱物の分離 に対する適用性については, 数多くの研究 が進められている。その幾つかを紹介する とつぎのようである。まずュールクリーニ ングに対する適用性試験については，米国 における試験研究の状況を俣川ら ${ }^{54)}$ が詳細 に述べている。また堀田ら ${ }^{55}$ は陶磁器原料, 珪砂粉, 低品位へマタイトに対する H G M $\mathrm{S}$ とシリカ逆浮選の組合せ処理, スペキュ ラーヘマタイト鉱からの superconcentrate の製造，ボーキサイト鉱および同種人工試 料の脱鉄, 石炭の脱灰, 低品位ウォルフラ マイト鉱の粗選, 選鉱廃水処理, 製紙工場 廃水処理, 地熱熱水の脱砒・脱シリカに対 しH G M G を適用した研究結果を報告して おり，陣内ら ${ }^{56)}$ はビリトンカオリンの精製 にHGMSを適用した結果を報告し，また 熟見ら ${ }^{57) 58)}$ は岩手硬質粘土の脱鉄と粘土 中の黄鉄鉱の除去に本法を用いた結果を述 べている。鄭ら ${ }^{59) 60)}$ は中国産へマタイトの 分離にHGM S を適用した研究結果を報告 しており，また金ら ${ }^{61) 62)}$ は硫化鉱物の分 離に本法を用い，黄銅鉱と方鉛鉱の分離を 行なつた結果を述べている。一方Taha ${ }^{63)}$ はへマタイトと石英の人工混合試料を用い てHGMSにおける捕捉性と選別性につい て基礎的研究を行ない, 在来型の磁選機に よる粗粒強磁性鉱物の分離と H G M Sによ る微粒弱磁性鉱物の分離との間に高度の類 似性があることを見いだしている。

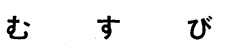

本資料は1983年に開催された MM I J / Aus IMM Joint Symposium において著 者が行なつた講演を基にし, その後調査し てえた資料を加えてまとめたものである。 磁選法はよく用いられる分離法のひとつで あり，小規模に行なつているところを含め れば, その工場の数はおびただしいものに なるであろう。ここではわが国とその周域 において磁選を主選法としていた鉣山の記 録をとどめることに重点をおいた。往年盛 んに操業していた鉱山でも, 今は閉山して いて公式の記録が残つていないものも多く， これらについては, 当時その衝にあつた方 々から個人的に資料を提供していただいた。 ここに深く感謝の意を表します。このよう な次第で調査の行き届かなかつた点も多々 あり，記事に濃淡の差が生じてしまつたが， これらの点については今後ともご教示を賜 わることができれば幸いである。

\section{文献}

1) Gunther, C.G.: Electro-Magnetic Ore Separation. New York, Hill Publishing, 1909

2）堀田祐邦 - 大森勝朗 - 俣川恭輔 - 中田三郎 : 浮選, 26 (1979) 57

3) コールム, H., J.オーバートニーフォー, D. ケランド（河合七雄訳）：日経サイエ ンス, No.1 (1976)

4) Gaudin, A.M.: Principles of Mineral Dressing. New York, Mc GRAV-HILL B ook Co., 1939

5) 加知 学 -堀田祐邦: 昭和 60 年度全国地 下資源関係学協会合同秋季大会分科研究会 資料 $[\mathrm{V}], 20$ (1985)

6) 大山正 -下飯坂潤三・長谷部茂・前田信秀 : 日本鉱業会誌, 76 (1960) 88

7 ) 三菱電機 (株)：DA-8520-3B 型磁気選 別機による選鉱試験, 1 (1962)

8) 小林敏夫 : 東北鉱山, 10 (1963) 88

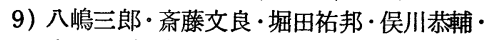
中田三郎 : 粉体工学会誌, 18 (1981) 28

10) 八沜三郎：日本鉱業会誌, 98 (1982) 654

11）粉体工学会編 (八沜三郎分担執筆) : 粉体 工学便覽, 日刊工業新聞社 大阪 (1986)

12) 伊井谷鋼一編 (八嶋三郎分担執筆) : 粉体 工学ハンドブック, 朝倉書店 東京 (1965)

13）中川一郎 : 日本鉱業会誌, 77 (1961) 740

14) Parker, M.R.: Com temp. phys., 18 (1977) 279

15）片岡昭夫：日本鉱業会誌, 98 (1982) 776

16) Eng. Min. Jour ., 133 (1932) 544

17) Eng. Min. Jour., 134 (1933) 123

18）八鴆三郎 - 粟野 修: 東北鉱山, 15 (1969) 82

19) 藤田重明: 電気試験所研究報告, $N_{0} \cdot 488$ (1947) 1

$20 ）$ 野村賢造 : 日本釷業会誌, 58 (1942) 555

21) 江刺鉱山社内報, (1980)

22）佐原猛：日本鉱業会誌，77 (1961) 751

23) 私信による

24) 私信による

25）日鉄鉱業 (株) : 四十年史, (1979) および 日鉄鉱業 (株) 資料

26）日本鉱業会誌, 38 (1922) 791

27）日本鉱業会誌, 39 (1923) 642

28）日本鉱業会誌，40（1924）472

29）(株) 昭和製鋼所：日本鉱業会誌，55 
(1939) 692

$30 ）$ 梅根常三郎: 鞍山鐵鋼会雑誌, 第 11 号 (1924) 1093

31）俵 国一: 鞍山鐵鋼会雑誌，第 14 号 (1925) 245

32）足立祐一：鞍川鐵鋼会雑誌，第16号 (1925) 493

33）梅根常三郎：鞍山鐵鋼会雑誌，第 52 号 (1934) 81

34) Research and Statistics Division, Minister's Secretariat, Ministry of International Trade and Industry : Mining Yearbook of Japan. (1955)

35) 高橋英男 : 日本鉣業会誌, 86 (1970) 737 36）私信による

37) 東 勝・高玉健一: 浮選, 26 (1979) 148

38）武田宏一：日本鉣業会誌，98 (1982) 854

39）私信による

40）新居治男：日本鉱業会誌，97（1981）792
41）私信による

42) 原田源三郎・谷川一明 : 浮選,29(1982) 32

43）私信による

44) 私信による

45）私信による

46) 日本エリーズマグネチックス(株)資料 (1984)

47）日本エリーズマグネチックス(株) 凟料 (1985)

48) 竹内正勝 - 安井 弘 - 真部東雄 · 伊藤㻟磨 八嶋三郎：日本鉱業会秋季大会分科研究会 資料 $\mathrm{L}-4 ，$ （1976） 1

49）日鉄鉱業(株)資料，(1986)

50) 大同特殊鋼 (株) 資料，（1985）

51) 私信による

52) 伊藤明男 : 浮選, 32(1985) 184

53) 大同特殊鋼 (株) 資 料, (1985)

54 ）俣川恭輔・中田三郎・堀田祐邦 : 浮選, 28 (1981) 49

55) 前出 2)
56) 陣内和彦・石橋修・河口純一・岸川忠张・ 徳久嘉信：浮選，31（1984）229

57 ) 驚見新- - 伊藤信一・鳥居一男 - 岡田豊明 . 岡原義旦: 浮選, 32 (1985) 109

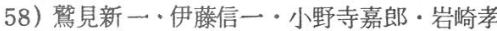
志・鳥居一雄・岡原羕旦：ibid..,163

59 ）鄭 龍熙・中塚勝人・下飯坂潤三：日本鉣 業会誌, 98 (1982) 575

60) Jurng, L.S., Nakat suka, K. and Shimoiizaka, J.: Annual Conference of MMIJ, Min.Met. Inst ., Japan, Tokyo, (1982) 247

61) Kim,Y.S., Fujita, T. and Shimoi izaka, J. : ibid., 55

62) Kim,Y.S., Suzuki, T., Konosu, A., Matsuoka, I and Shimoiizaka, J. : ibid., 365

63) Taha Abbas Taha ·堀田浩充。八嶋三郎 : 日本鉱業会, 昭和 61 年度研究. 業績発表 講演会講演要旨集，(1986）122

\section{新刊紹介}

培風館, 1986

\section{A 5 230頁 3,900円}

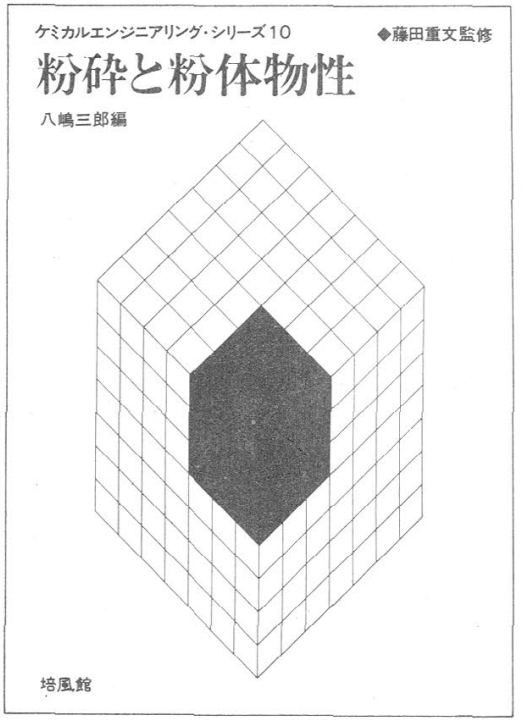

\section{八嶋三郎編“粉砕と粉体物 性”}

〔ケミカルエンジニアリングシリーズ10]

\section{書 評}

「粉砕」はそのことばの意味するところ とはうらはらに，きわめて建設的な単位操 作であつて，古くから多くの工業プロセス の基礎となつている。それにもか加わらず 粉碎に関してまとめられた参考書，教科書 は国内外においてきわめて少ないので，本 書は大いに注目されるところである。

著者らによれば，昨今における各種機能 性材料の設計要素となる微粒子の製造の重 要性にかんがみ，粉砕操作のミク口的究明 を計ることを念頭において本書がまとめら れている。すなわち，まず脆性体の破壞に 関するGriffith の理論から話をおこし

（第1章），次に粉砕に関連した粒子の基 本的特性つまり粒度 (分布)，比表面積, 形状およびそれらの測定 (決定 ) 方法，さ らに粒子の付着力について説明を行なつて いる (第 2 章)。そして著者らの永年にわ たる研究を通じて得られた知見をまとめた
いわば本書の中核をなす第 3 章，第 4 章で は，単粒子破砝について，多くの実験デー 夕にもとづく材料力学および材料强度学の 立場からの詳細な説明がなされている。そ して次の第 5 章では「集合粉砕」という標 題の下に，工業的に実施されている「粉砕 について, 速度論, 閉回路，単粒子破砕と の比較, 粉砕限界と助剂, 摩砕, 優先粉砕 などの項目別に，説明が加えられている最 後の第 6 章では対象を脆性体から粉体層へ 移し，いわゆる「粉体層のすべり」につい ても概説している。

本書は，著者らの貴重な実験データが盛 り込まれている点で，関係専門家のための 参考書としての価值を十分に備えているば かりでなく，解答つきの例題がところどこ ろに用意されているところからみて，学生 の教科書としての側面をも有し，非常に欲 張つた内容となつており，本書の多方面て の利用が期待される。(東大 岡野靖彦)

\section{鉱業史凟料半田銀山の旧坑 (3)}

最近旧坑の実際を見分するために，半田の地を訪れたが，まこ とに見事な旧坑で，驚いたことには奥まつた一画には照明用の篠 竹（灯竹）が炭化して山積みされている。坑内照明としては古く 松明（たいまつ）紙燭（ししよく），さざえ・あわび貝殼を利用 した灯心・油による灯火等のほかに，きわめて多数の篠竹が消費 されていたことは絵巻物絵図で明らかであつたが，現物にお目に かかつたことはなかつた。2〜3mの範眀に積重ねてあつたものか 炭化したままこんもり盛り上つている。また別のところには坑木 （長さ 3 尺）が積上げられそのまま腐つている箇所もあり，恐ら く坑口近くの置場であつたものであろう。いずれにしても貴重な 文化財である。 (葉賀七三男)

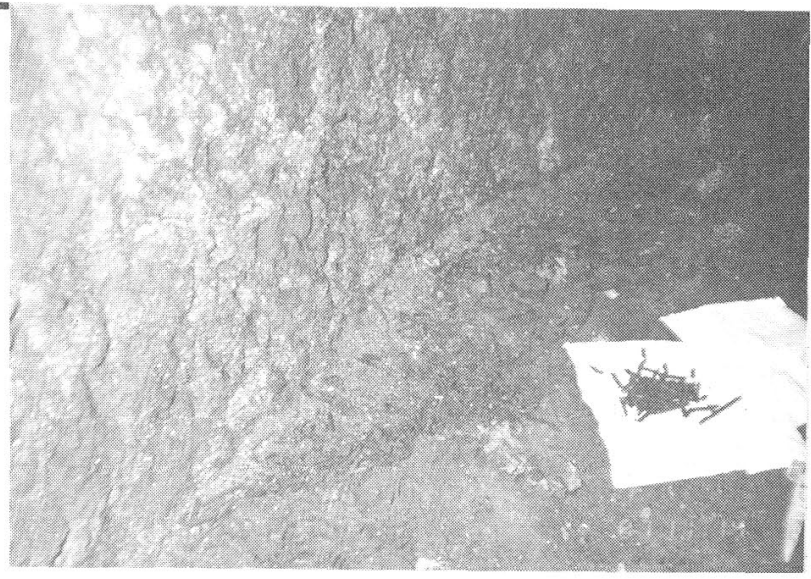

